\title{
Urban Poverty: A Study of Income Patterns and Processes of the Poor Families in Kathmandu
}

\author{
Kedar Dahal \\ Associate Professor, Tribhuvan University, Kathmandu, Nepal \\ Email: dahalkedar@hotmail.com
}

\begin{abstract}
The poor are highly migrate from the surrounding districts of Kathmandu valley and largely dependent on direct cash income from the informal activities. Casual wage labor, petty trade and private and professional services are common livelihood activities. However, availability of income generation activities remains largely irregular and depends on the season, gender, age of person, ethnic and education background. Foreign employment, skill-based activities and petty trade fetch the highest return. It is also found that the level of family income is determined not only by ethnic background; but there are other factors, for example family structure, working hours, nature of work and seasonality. There is a significant impact of education and working hour in household income. Poor are assets of urban economy. We could not neglect them. They are hard working and decent people. But poor policy and attitude makes them highly vulnerable in the urban environment. However, all people living in the squatter or slum are not only poor but some of them are economically well-off, though they have poor accessed of modern banking and financial institutions, in many cases, banking policies discouraged them for providing credit facilities.
\end{abstract}

Key Words: Poverty Pockets, Communities, Urban, Livelihood

\section{INTRODUCTION}

In Nepal, urban poverty is increasing at high pace. During a decade long political turmoil in the country, many poor communities have chosen Kathmandu as a best destination for securing their lives and properties. The lack of opportunities and increasing psycho-political threat in the rural areas are responsible for such a situation.

Urban poor are the source of cheap labor force as well as service provider in the informal sector through the activities like, vending, shoe making, driving and construction work. Unfortunately, they are largely ignored in the development process and labeled as illegal and unauthorized settlers. The poor are marginal communities who migrate to city and live in squatter settlements on the periphery of cities; they include high proportion of illiterates and unskilled laborers. They are socially, economically and politically marginal (Harpha, Lusty and Vangham 1988); and are spatially separated from the nearby neighborhood. A general typology of low-income settlements developed in and around the city is presented in Table 1. 
Table 1: General Typology of Poor and Marginal Communities

\begin{tabular}{lll}
\hline Types & Land Acquisition Status & Physical Characteristics \\
\hline $\begin{array}{l}\text { Squatter } \\
\text { Settlements }\end{array}$ & $\begin{array}{l}\text { Invasion of public or private } \\
\text { land }\end{array}$ & $\begin{array}{l}\text { Middle and periphery where security of tenure then } \\
\text { upgrading is likely. }\end{array}$ \\
\hline $\begin{array}{l}\text { Squatters / } \\
\text { Shanty Towns }\end{array}$ & $\begin{array}{l}\text { Dominant of squatters } \\
\text { (usually renters) }\end{array}$ & $\begin{array}{l}\text { Mostly downtown and around city centre, small plots } \\
\text { with few public amenities and little prospect of their } \\
\text { provision. Likelihood of self help improvement. }\end{array}$ \\
\hline $\begin{array}{l}\text { Street Sleepers } \\
\text { / Dwellers }\end{array}$ & $\begin{array}{l}\text { May have regular sleeping } \\
\text { place, Invasion of public } \\
\text { road/land }\end{array}$ & $\begin{array}{l}\text { Downtown/inner city. Shelter removed daily often } \\
\text { associated with workplace. }\end{array}$ \\
\hline Slum & $\begin{array}{l}\text { Converted large houses of } \\
\text { permanent or semi- } \\
\text { permanent structures, usually } \\
\text { rentals. }\end{array}$ & $\begin{array}{l}\text { Mostly downtown. An increasing portion of new } \\
\text { rental accommodation in older irregular settlements. } \\
\text { Single room per family and share the same. }\end{array}$ \\
& Makeshift/Mobile & Mostly dominated in the central of the city. \\
\hline $\begin{array}{l}\text { Vendors and } \\
\text { Hawkers }\end{array}$ & &
\end{tabular}

In Nepal, squatter settlements, slums, street dwellers, vendors, marginal farm families, and scavenging groups are categorized as poor urban communities. Such communities are concentrated either on the bank of rivers or in the open space near the historical and religious monuments. Hawkers and vendors are concentrated in the city center, religious places and tourist destination sites. Hawkers and vendors are another form of urban poverty in the city, and they are engaged in selling either agricultural products or cloth items or preparing fast food. In a city like Kathmandu, where the price of land is skyrocketing purchasing a parcel of land is beyond the capacity of low income group. In this background, the main objective of this study is to examine an economic status of the poor communities and their access of financial institutions in Kathmandu.

\section{METHODS AND APPROACHES}

This study, therefore, is based on the primary and secondary data and information collected by using qualitative and quantitative tools and methods. Face to face interactions with local people and resource persons, focus group discussions, key informant interview and informal conservations were conducted to gather data and information.

In this study, a multi-stage sampling framework is widely used. According to this framework, the study area is divided into different zones, for example, central, middle and periphery. In this study, apart from the previous methodologies adopted by several researchers, functional and urban expansion issues are also taken into consideration for zoning purpose. Therefore, finally, the following procedure has been applied for the selection of survey households and interview:

Stage I; Identification of poverty pockets, household and population: Altogether 34 poverty pockets are identified in the metropolitan city. Altogether 2298 household and more than 11,000 population were recorded in the poverty pockets in the metropolitan city.

Stage II; Zoning of poverty pockets: Three zones e.g. central, middle and periphery $^{1}$ are defined for the study purpose based on the previous literature, observation (functional and urban expansion of the city), land use map. There are 
10 poverty pockets, which belong to the central zone, 16 in middle and 8 poverty pockets are under periphery zone in Kathmandu (figure 1).

\section{Figure 1: Poverty Pockets in Kathmandu Metropolitan City}

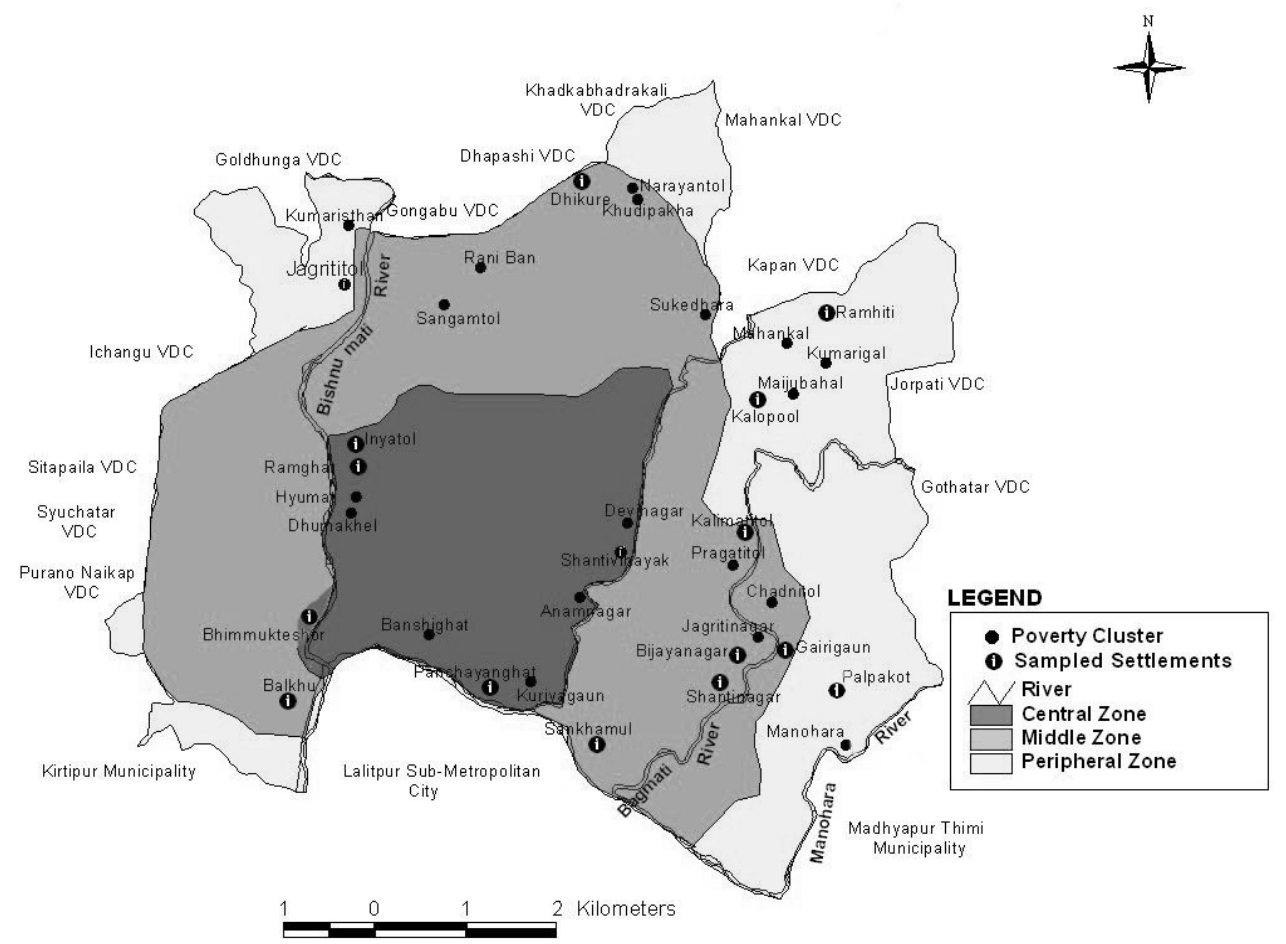

Stage III; Selection of the poverty pockets and determine the sample size: $50 \%$ (i.e. 17) out of the 34 poverty pockets from the three stratums i.e. central, middle and periphery are selected by using random number table. Due to the limited budget and time framework, details of all household in the selected poverty pockets in Kathmandu was not possible; therefore, out of the total households in the sampled poverty pockets, only $20 \%$ are chosen from each stratum for the study that is 314 households.

Sampling method and sampling interval: Simple random sampling without replacement is used to identify the household for the interview from the sampled poverty pockets in Kathmandu. Then, systematic sampling method is applied to identify household for data collection purpose. In the systematic sampling where only the first case is randomly selected, and the randomly selected first case is called 'random start number', thereafter, every $k_{t h}$ case is selected. 'Sampling interval' is calculated from the mass (universe) in relation to the required number of 
sample from the universe. Due to the large universe and sporadic location of poverty pockets, probability systematic sampling technique ${ }^{1}$ is used.

Apart from the household survey, Focus Group Discussion (FGD), Key Informant Interview (KII), Informal conservations, Observation and some case studies have also were also highly used to gather data and information.

Statistical and non-statistical tools are widely used to analyze data and information. Statistical tools, for example Chi-square test and multiple regressions are used; and income inequality is measured by using Gini-coefficient.

Chi-square (obtained) $\left(x^{2}\right)=\frac{\left(f_{o}-f_{e}\right)^{2}}{f_{e}}$

(Healey 1999)

Where,

$f_{o}=$ observed frequencies.

$f_{e}=$ expected frequencies.

Multiple Regressions are calculated by using SPSS. Following formula can be given to explain multiple regressions:

$\mathrm{Y}=\mathrm{a}+\mathrm{b}_{1} \mathrm{X}_{1}+\mathrm{b}_{2} \mathrm{X}_{2}$ (Healey 1999; Bowerman and O'Connell 1990; Pal 1982)

Where,

$\mathrm{Y}=$ dependent variables.

$\mathrm{a}=$ point of intercept with the $\mathrm{Y}$-axis.

$X_{1}$ and $X_{2}=$ two independent variables being considered.

$b_{1}=$ the rate of change in $Y$ for each unit change in $X_{1}$, with $X_{2}$ held constant. It is called a regression coefficient.

$b_{2}=$ the rate of change in $Y$ for each unit change in $X_{2}$, with $X_{1}$ held constant. It is also called a regression coefficient.

Gini-coefficient is calculated as:

$$
\left.G c=\frac{1}{(100)^{2}} \underset{i=0}{i=n} X_{i} Y_{i+1}-\sum_{i=0}^{i=n} X_{i+1} Y_{i}\right]
$$

Who are Urban Poor Communities in Kathmandu?

Nepal Living Standard Survey (NLSS) 2003/04 defined Rs. 11,056.8 as the poverty level for urban areas of Kathmandu valley which consisted of $60.8 \%$ for food and $39.2 \%$ for non-food items. Lumanti (2005) applied cost of basic needs metho ${ }^{2}$ for

\footnotetext{
${ }^{1}$ This technique is useful when sampling unit vary in size because it ensures that household in larger units have the same probability of getting into the sample as those in smaller ones and vice versa. Using this technique also helps in making fieldwork because a predetermined number of respondents are interviewed in each selected unit (Jacobsen 2008).
} 
the Kathmandu Metropolitan City that was also adopted by NLSS 1995-96 and NLSS 2003-04. Based on this method, poverty level has been defined as below (Table 2).

Table 2: Per-capita Income Ranges and Poverty Status

\begin{tabular}{ll}
\hline Income Ranges (Rs.) & Status \\
\hline Less than 12,000 & Poor \\
\hline $12,000-25,000$ & Lower Medium \\
\hline $25001-60,000$ & Medium \\
\hline Above 60,000 & Upper Medium and Rich \\
\hline
\end{tabular}

Accordingly, persons having income less than Rs. 12,000/person/annum categorized as poor, and persons having Rs. 12,001-25,000 /person/annum have been categorized into lower medium people. And income more than Rs 60,000 represented as an upper medium and rich class (Lumanti 2005, 12).

However, actual data of the urban poor communities in Kathmandu metropolitan city has not been published yet. Even, the metropolitan city does not have an accurate figure of urban poor. Who actually are poor and how many of them are living in the metropolitan city? What are the dimensions of urban poor and what are they doing for their livelihood in the metropolitan city? These are some of the major issues debated in the contemporary urban literature in Nepal. There is no any accepted definition of urban poverty in Nepal. In many cases, social researchers have recognized that poor urban communities are those who are living in the slums and squatter settlements (permanent, semi-permanent or temporary or legal or illegal) either in the open spaces, religious sites or on the bank of the rivers. Lumanti (2005) defined 'poor' as those people who have annual income less than Rs. 12,000 . At this level, $13 \%$ people and $8 \%$ households in the metropolitan city were found below the poverty level.

Although, squatter settlements, slums, street dwellers, vendors, marginal farm families, and scavenging groups are categorized as poor urban communities. Such communities are concentrated either on the bank of rivers or in the open space near the historical and religious monuments.

Origin and Migration

Survey revealed that about $64 \%$ households of urban poor in Kathmandu are migrants, mostly from outside the valley. Three scenarios of migration have been identified in this study; first, migration from the central hills and mountain region consists of more than $60 \%$ of total migration; second, migration from eastern Terai is about 14\%; and third, eastern hills and mountain represents almost $15 \%$ of the total migrants in the poverty pockets (Figure 2). 


\section{Figure 2: Origin of Poor Communities in Kathmandu}
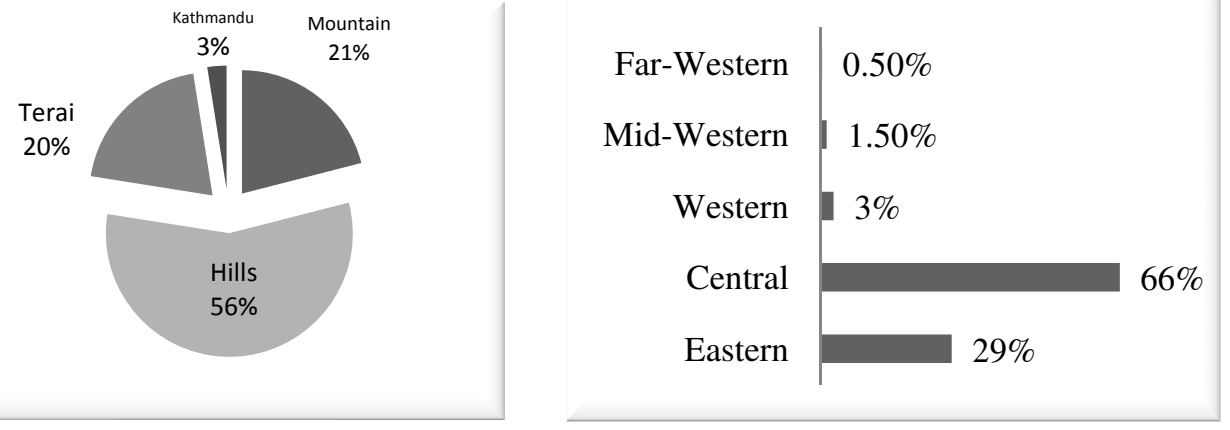

Outnumber of immigration reported during the susceptibility of the conflict. A study of Pradhan $(2008,36)$ shows that $62 \%$ poor urban households are migrants, of which $33 \%$ has been reported recent migrant (i.e. for 5 years back). That was the period in which the people's war (as frequently announced by Maoist) was on the climax. Most of them are migrants from hills (66\%) and central (71\%) region. Out of the total, nearly $3 \%$ migrated due to the conflict and some are refugees (Pradhan 2008, 37). Contrary to this figure, Shrestha (2008) has indicated that conflict $(26 \%)$ is one of the major reasons of immigration in Kathmandu who lived either in temporary/semi-permanent or permanent slums/squatter settlements. Such difference in estimation is due to the methodological variation adopted by them. It also depends on the respondent bias and sample design of settlements and households. Another study of Dawadi (2008) exhibits that $75 \%$ of commercial vendors in Kathmandu city are migrants of which $57 \%$ migrated during the last 10 years, which was the period of political turmoil, insurgency and insecurity in the country. Raut (2008) has also indicated that conflict is one of the core causes of immigration in Kathmandu. Timalsina (2007) has found that the increase in number of street vendors in the urban areas particularly in Kathmandu in recent years due to rural conflict and displacement. This study also shows that street vending is an opportunity to rural poor for making a living in the urban areas.

\section{Growth and Distribution of Poverty Pockets in Kathmandu}

In the KMC, about 11,862 people are living in the 61 different squatter settlements and slum areas in 2000 whilst the squatter population in 1988 was only 3,665 in 24 different settlements. The latest survey conducted by Lumanti in 2008, shows that there are 45 poor pockets and 13,243 people on the banks of Bagmati River and its tributaries in Kathmandu (Table 3).

Table 3: Growth of squatter settlements in Kathmandu

\begin{tabular}{llll}
\hline Years & \# of settlements & Number of HHs & Total population \\
\hline 1985 & 17 & - & 2,134 \\
\hline 1988 & 24 & 348 & 3,665 \\
\hline 1992 & 33 & 1,271 & 6,355 \\
\hline 1996 & 47 & 1,783 & 8,927 \\
\hline 1998 & 49 & 2,021 & 10,323 \\
\hline 2000 & 61 & 2,031 & 11,862 \\
\hline 2008 & 45 & 2,844 & 13,243 \\
\hline \multicolumn{2}{l}{ Sources: KMC/World Bank 2001, Lumanti 2008 }
\end{tabular}


Most of the poverty pockets are emerging on the banks of Bagmati River and its tributaries. These are highly vulnerable in terms of river pollution and flood, poor sewage and drainage, health and sanitation, congested and narrow lanes. Some poverty pockets belong to an indigenous settlement e.g. Newar communities, in the Vishnumati river from Sobha Bhagawati to Teku Dovan. Those group themselves would like to be categorized as 'Swabas/ instead of Slum or Squatter. Study shows that more $81 \%$ squatter families in Kathmandu are living on the banks of Bagmati and its tributaries (Lumanti 2008, 14). Balkhu and Panchayanghat (Thapathali) are relatively new poverty pockets developed after 2005 . Temporary with plastic roof having one or two rooms and common toilet and open toilet practices are common characteristics of the newly growing poverty pockets. But others have, in most cases semi-permanent structure of housing and relatively well furnished houses compared to newly growing poverty areas. Distribution of poverty pockets in Kathmandu Metropolitan City is showing in Figure 1.

\section{RESULTS AND DISCUSSION}

\section{Livelihood and Urban Poor}

The poor urban community has been involved in the diversified livelihood activities, and most of them (90\%) are involved in informal sector (Pradhan 2008, 38). Selfemployment, daily wage unskilled work, domestic help, public transport work e.g. driving and fare collection, transportation of building materials e.g. sand, concrete and cement, waste collection, pretty trade, running hotels, small restaurants and private tuitions are supporting livelihood activities of the poor urban communities.

Urban poor are very close to the radical political parties. In the case of Kathmandu, many of them are associated with left-wing political parties; hoping that the radical government would provide land, shelter, employment and urban services to them. This is one of core reasons for increasing inflows of rural poor in urban area including Kathmandu, especially after the democratic movement in 1989/90.

Table 4: Percentage of Poor Household Involved in Political Activities

\begin{tabular}{ll}
\hline Nature of Participation & Percentage \\
\hline Political Rallies ad Gatherings & 81.69 \\
\hline Information and Knowledge Dissemination & 11.27 \\
\hline Decision Making and Implementation & 5.63 \\
\hline Policy Formulation & 1.41 \\
\hline Total & $100.00(\mathrm{~N}=71)$ \\
\hline
\end{tabular}

The table 4 shows the nature of involvement of the poor communities in the current politics. Those who are not interested in politics have cited three reasons; firstly, they don't know about party politics (54\%); therefore, they usually are not interested in participating in the parties' activities, rallies and gatherings. Secondly, they know about the ongoing politics in the country, but they largely ignore it because they first need to secure their daily livelihood (36\%); and thirdly, they also know about the politics but could not appear in the politics due to their family restrictions (10\%). 


\section{Financial Asset and Access}

Financial assets are a means of subsistence in urban area which is highly dependent on cash incomes, either directly through wage labor or indirectly through the production and sale of goods and services or loans/indebtedness. Generally, the urban poor have better access to income through the employment and market opportunities that cities offer as compared to rural areas. Nonetheless, access to employment in the informal sector in Kathmandu is strongly related to caste or ethnicity, as different communities have established economic niches in areas of employment, production or markets. Access to credit, either from the formal market, for example, banks and financial institutions; or/and informal credit sources' e.g. cooperatives and saving and credit groups, are another asset for urban poor. However, due to the weak social, economic and political networking, formal banks and financial institutions usually do not provide credit/loan to the poor. As a result the poor have access credit/loans from the informal sources, and each poverty pocket has established its own saving credit groups.

Community-managed micro finance is an alternative means to build assets and to access loans. Saving and credit groups provide access to support networks. Locally established saving and credit groups/cooperatives have acquired formal legal status and are delivering credit services to the members. There are 20 cooperatives, 463 groups and 11,032 members in poverty pockets in the metropolitan city; and handle fixed, saving and current account of the member. They manage fund of about Rs 358, 000, 00 and disburse loan to their members (Lumanti Data Sheet 2009; KII, February 2010). The groups manage the funds and grant small loans of Rs 500 to Rs 300,000 to individual members. These saving and credit groups have been joined their hands to set up cooperatives, a more secure formal financial institution. Loans are used for trade/business (37\%), land purchase (20\%), housing $(14 \%)$, payment of loan (12\%) and foreign employment $(7 \%)$; and the interest rates for all cases range from 12-16\% annually (Gyanjyoti Mahila Utthan Saving and Credit Cooperative Limited, February 2010). However, FGD with the beneficiaries indicated that loans were far more accessible to better-off and bettereducated groups. Nonetheless, financial assets are one of the most important aspects of poor for livelihood but it is also the most problematic feature which obstructs them to get credit.

Study shows that only $42 \%$ households have access to [local] social and community organizations. Nearly $40 \%$ family members are associated with more than one organization. Among others, local savings and credit groups are more prominent institutions that increase social ties and relations with other members of the communities. Out of the total family that have access to social and community based organizations, nearly $61 \%$ of them are associated with savings and credit groups/cooperatives. More than $70 \%$ families living in the peripheral zone of KMC, while it is only $43 \%$ in the core zone associated with saving and credit. 


\section{Livelihood Activities, Household Income and Expenditure}

The growth of informal wage helps in reducing the incidence of urban poverty (Kar and Marjit 2009, 636), even though they have no fixed place for work, no fixed working hours, no regular wage and security of job. In this sense, they are economically vulnerable group in the urban society. Age, level of education and gender are key determinants affecting the level of household income among the urban poor. There are, for instance in Dhaka (Bangladesh), less possibilities to be poor in those household in which the proportion of male adolescence aged 9-14 is higher, similarly educated head of households have less possibility of being poor, higher the share of adults, lower the possibility of being poor (World Bank 2007,15).

Together with above mentioned factors, gender is also a determinant of household income particularly in Kathmandu. Higher the proportion of female in the family, higher the chance of being poor. This is obvious that poor women are physically weak due to the high fertility/reproductive rate and are involved mostly in the home-based and casual work in construction sectors and petty business near the poverty cluster (FGD, February 2010). In this perspective, it is true that, family socio-economic status is based on family income, parental education level, parental occupation and social status in the community (Baker and Schuler 2005).

An average income of poor urban in Kathmandu is Rs 250/day/family (Table 5). Foreign employment seems to be an important source of household income. But very few households are involved in the foreign employment. It also depends on the financial and social networking and individual willingness to go abroad to support his/her family income. Besides this, sample data revealed that skill-based activities fetch comparatively higher returns than others. For example, income/day from driving, carpentry and masonry, underling private and professional services has better increases. Petty business and contractual work are also a major source of family income. The worst activity in terms of income is domestic helper (Rs $86 /$ day) where only women are involved, followed by agriculture and livestock (Rs 133 /day). Overall, the highest return is calculated from contractors in construction activities (Rs 625/day) followed by driving (Rs 600/day). An earlier studies in Afghanistan reveals that urban poor have earned Afghan Afghani (Af) 116, 123 and 29 (equivalent to Rs 178,189 and 45 respectively ${ }^{3}$ from casual work, selfemployment and home-based activities respectively (Schutte 2006, 17); while this is Rs 242, 348 and 86 from casual work, self-employment and home-based activities respectively in Kathmandu (Table 6). 
Table 5: Household Income and Expenditure (Average Rs/day by Activities)

\begin{tabular}{lllr}
\hline Activities & Income & Expenditure & Balance/Saving \\
\hline Foreign Employment & 441 & 186 & 255 \\
\hline Driving & 360 & 241 & 119 \\
\hline Petty Business/trade & 336 & 209 & 127 \\
\hline Contract \& Contractors & 330 & 231 & 99 \\
\hline Carpentry and Mason & 293 & 169 & 124 \\
\hline Service (P) & 226 & 144 & 82 \\
\hline Wage/Labor & 209 & 134 & 75 \\
\hline Service (G) & 174 & 125 & 49 \\
\hline Agriculture and Livestock & 133 & 76 & 57 \\
\hline Domestic Helpers & 86 & 55 & 31 \\
\hline Others & 181 & 117 & 64 \\
\hline Average & 250 & 153 & 97 \\
\hline Note: 'P' denotes private and professional services; 'G' denotes government services &
\end{tabular}

Table 6: Comparative Overview of Livelihood Activities

\begin{tabular}{lllllll}
\hline \multirow{2}{*}{ Urban } & \multicolumn{3}{c}{ Activities (Percentage of Poor Engaged) } & \multirow{2}{*}{ Sources } \\
\cline { 2 - 6 } & $\begin{array}{l}\text { Self- } \\
\text { employed }\end{array}$ & $\begin{array}{l}\text { Casual } \\
\text { Work }\end{array}$ & $\begin{array}{l}\text { Home- } \\
\text { Based } \\
\text { Work }\end{array}$ & Services & $\begin{array}{l}\text { Not } \\
\text { Specified }\end{array}$ & \\
\hline Kathmandu & 25.51 & 33.17 & 1.00 & 25.35 & 15.00 & Self Study \\
\hline Kabul & 40.00 & 32.00 & 19.00 & 6.00 & 3.00 & $\begin{array}{l}\text { Beall and } \\
\text { Schutte 2006 }\end{array}$ \\
\hline Dhaka & 52.00 & 12.00 & NA & 17 & 19.00 & $\begin{array}{l}\text { Hossain 2005 } \\
\text { (Modified) }\end{array}$ \\
\hline Indian Cities & 32.00 & 27.00 & NA & 41.00 & NA & $\begin{array}{l}\text { Sarin and Jain } \\
\text { 2009 } \\
\text { (Modified) }\end{array}$ \\
\hline Ugandan Cities & 31.00 & 20.00 & NA & 26.00 & 23.00 & $\begin{array}{l}\text { Bryceson et al. } \\
\text { 2003 } \\
\text { (Modified) }\end{array}$ \\
\hline
\end{tabular}

For easy interpretation, the household incomes are ranked (Table 7, Figure 3). Data revealed that $40 \%$ households have an average income in between Rs $201-400 /$ day and one-fifth Rs 501-1000/day. It is also found that more than $6 \%$ households have average income above Rs $1000 /$ day which is almost equivalent to middle class income of Kathmandu ${ }^{4}$. Gini coefficient ${ }^{5}$ of 0.34 indicates the level of concentration of income of families living in the poverty pockets (Annex).

Table 7: Ranking Household Income (Rs/Day)

\begin{tabular}{llllllllllll}
\hline $\begin{array}{l}\text { Income } \\
\text { Rs/Day }\end{array}$ & $\begin{array}{l}\mathbf{1 0 0} \\
\text { and } \\
\text { Below }\end{array}$ & $\begin{array}{l}\mathbf{1 0 1 -} \\
\mathbf{2 0 0}\end{array}$ & $\begin{array}{l}\mathbf{2 0 1 -} \\
\mathbf{3 0 0}\end{array}$ & $\begin{array}{l}\mathbf{3 0 1 -} \\
\mathbf{4 0 0}\end{array}$ & $\begin{array}{l}\mathbf{4 0 1 -} \\
\mathbf{5 0 0}\end{array}$ & $\begin{array}{l}\mathbf{5 0 1 -} \\
\mathbf{6 0 0}\end{array}$ & $\begin{array}{l}\mathbf{6 0 1 -} \\
\mathbf{7 0 0}\end{array}$ & $\begin{array}{l}\mathbf{7 0 1 -} \\
\mathbf{8 0 0}\end{array}$ & $\begin{array}{l}\mathbf{8 0 1 -} \\
\mathbf{9 0 0}\end{array}$ & $\begin{array}{l}\mathbf{9 0 1 -} \\
\mathbf{1 0 0 0}\end{array}$ & $\begin{array}{l}\text { Above } \\
\mathbf{1 0 0 0}\end{array}$ \\
\hline $\mathrm{HH} \%$ & 4.79 & 16.61 & 27.80 & 12.46 & 11.82 & 8.31 & 3.83 & 1.60 & 5.11 & 1.28 & 6.39 \\
\hline Total $(\%)$ & $100.0 ; \mathrm{N}=314$ & & & & & & & & & \\
\hline
\end{tabular}


Figure 3: Distribution of Family Income among the Poor

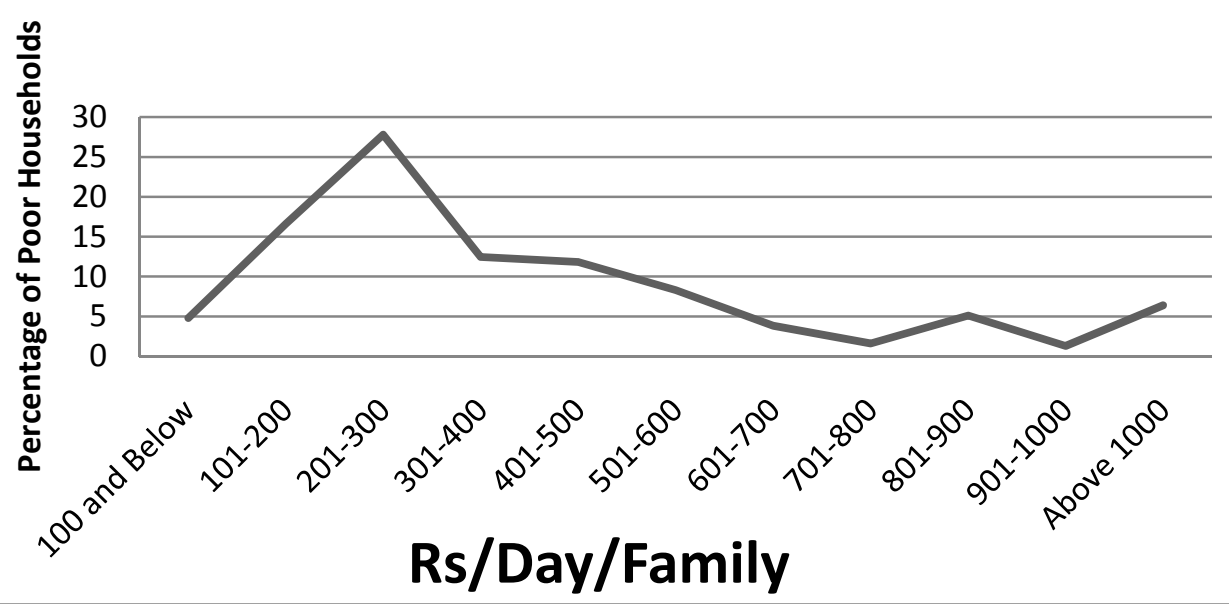

Level of income can also be described from the perspective of ethnicity. Survey revealed that about one-fifth household belongs to Brahmin/Chhetri, Janajaties, and Newar communities having an income up to Rs 200/day. Income ranges of Rs 201$500 /$ day is reported more by Dalits $(68 \%)$, followed by Newar $(62 \%)$, Janajaties/Minorities (53\%) and Brahmin/Chhetri (40\%). Brahmin and Chhetri are recorded higher incidence of lower income ranges (Rs up to 200/day) as compared with other communities in the poor urban pockets in Kathmandu. In addition, those households which have income Rs $100 /$ day or less reported more than fifty percent $(53.33 \%)$ in Janajati. Corresponding figure is only about $7 \%$ for Newar communities. About 9\% Dalit household record income of more than Rs 1000/day (Table 8). An earlier study shows that hill ethnic communities ${ }^{6}$ in Kathmandu metropolitan city are relatively poorer followed by Newar, Brahmin and Chhetri (Lumanti 2005, 26). In the case of urban poor, it is different where-in Dalits and Newars have comparatively poorer with low per-capita income and suffer poverty. Lowest average household income is found among Newar community (Rs 95/day) as compared to Brahmin/Chhetri (108/day) and Janajaties/Minoroties (Rs 105/day). The lowest per-head income calculated for Dalits is Rs 401/day as compared to Rs 510 for Brahmin/Chhetri communities. Chi-square $\left(\mathrm{X}^{2}\right)$ value however shows that household income and ethnic background are not related (Annex).

Table 8: Average HH Income by Ethnicity

\begin{tabular}{|c|c|c|c|c|c|c|c|c|c|c|c|}
\hline $\begin{array}{l}\text { Ethnic } \\
\text { Community }\end{array}$ & \multicolumn{11}{|c|}{ Income ( Rs/Day) } \\
\hline Brahmin/Chhetri & 40.00 & 26.92 & 22.99 & 10.26 & 18.92 & 30.77 & 16.67 & 60.00 & 31.25 & 50.00 & 30.00 \\
\hline Dalits & 0.00 & 9.62 & 17.24 & 15.38 & 5.40 & 3.85 & 8.33 & 0.00 & 6.25 & 0.00 & 15.00 \\
\hline Newars & 6.67 & 11.54 & 9.19 & 12.82 & 21.62 & 15.38 & 0.00 & 0.00 & 6.25 & 0.00 & 5.00 \\
\hline Others & 0.00 & 7.69 & 2.30 & 0.00 & 2.71 & 0.00 & 8.33 & 0.00 & 0.00 & 25.00 & 0.00 \\
\hline Total & 100.00 & 100.00 & 100.00 & 100.00 & 100.00 & 100.00 & 100.00 & 100.00 & 100.00 & 100.00 & 100.00 \\
\hline $\mathrm{N}=$ & 15 & 52 & 87 & 39 & 37 & 26 & 12 & 5 & 16 & 4 & $\begin{array}{l}20 \\
\mathrm{~N}=313\end{array}$ \\
\hline
\end{tabular}

Note: Figure parentheses represent percentage 
Average household income in the metropolitan city area has been found Rs 443/day/family. Among the sampled poverty pockets, Shantinagar, Bijayanagar and Ramhiti have almost double the household income of Kalopul (Rs 300/day). The lowest household income is recorded at Kalimatidol (Rs 355/day) followed by Balkhu (Rs 380/day) (Table 8). Study clearly shows that there is significant difference in household income among the sampled poverty pockets. For example, the lowest per capita income in Gairigaun is Rs 69/day/person as compared to highest in Narayantol and Panchayanghat of Rs 121/day (Table 9).

Table 9: Per-capita Household Income by Location (Rs/Day)

\begin{tabular}{llll}
\hline Location/Poverty Pockets & Household Income & Household Size & Per-capita Income \\
\hline Bhimmukteshwor & 404 & 4.7 & 86.00 \\
\hline Inyadol & 386 & 3.7 & 104.37 \\
\hline Panchayanghat & 434 & 3.6 & 120.54 \\
\hline Ramghat & 441 & 3.8 & 116.00 \\
\hline Shantibinayak & 478 & 5.6 & 85.30 \\
\hline Balkhu & 380 & 4.3 & 88.33 \\
\hline Bijayanagar & 569 & 4.0 & 142.36 \\
\hline Dhikure & 452 & 6.0 & 75.33 \\
\hline Gairigaun & 413 & 6.0 & 68.75 \\
\hline Kalimatidol & 355 & 3.7 & 96.67 \\
\hline Narayantol & 507 & 4.2 & 120.82 \\
\hline Shankhamul & 384 & 4.0 & 94.81 \\
\hline Shantinagar & 593 & 4.1 & 146.30 \\
\hline Jagrititol & 436 & 4.4 & 98.22 \\
\hline Kalopul & 300 & 4.0 & 75.00 \\
\hline Palpakot & 417 & 4.6 & 90.74 \\
\hline Ramhiti & 583 & 5.1 & 114.71 \\
\hline Average & 443.0 & 4.5 & 101.4 \\
\hline
\end{tabular}

The level of household income is highly fluctuating, and depends largely on the population characteristics such as age, gender, family structure and household size, nature of work, seasons and working hours. Some communities, particularly Newars, still practice a joint family system (FGD, November 2009) but new squatter settlement, for example Panchayanghat (Thapathali) has small household size e.g. 3.6, mostly in the age group of 11-30 years. In these types of community, they have either no children or 1-2 children and both male and female usually are involved in some kind of gainful activities. These household incomes are dependent on the seasonal work and the availability of work in the vicinity. Usually, poor have lower chances of earning income during the winter due to shorter day time and severe cold. Many of them do not get proper employment and travel distance for work to support their family livelihood (FGD, November 2009). It shows that poor people have low productivity of employment and consequently low level of income.

Average expenditure by the poor in Kathmandu is found Rs 153/day/family. Those people who are involved in driving or work as a contractor and those in construction, petty business and trade activities make highest expenditure and those who work as a domestic helpers and are involved in agriculture and livestock have record lowest level of expenditure (see Table 5). Poor households in Kathmandu metropolitan city spent nearly $52 \%$ of their income in food and fuel followed by transportation (20\%) and education (10\%). They spent only $5 \%$ in 
purchasing clothes and garments and about $8 \%$ spent on health (FGD, February 2010). These households do not usually send their children to private and boarding schools and do not have access to private hospitals and nursing homes due to high costs. Therefore, they have to patronize the local government schools and utilize Government/public (local) health posts and hospitals. There is increased awareness about the need for saving even from their limited income. In this field, local saving and credit groups and national organizations play a key role. They deposit certain amount of money on daily or monthly basis in the local credit cooperatives. The poor have no access to the national level banks and financial institutions due to their illiteracy; they are largely ignored by the banking sectors (FGD, December 2009).

\section{Correlations among the Socio-economic Parameters}

An attempt has been made to examine the relationship between income and other socio-economic parameters such as family size, education, landholding and working hours by using linear multiple regression. The unit of analysis of these variables are income in Rs/day, number of family members, education index (the sum of formal classes divided by total number of family), size of land holding (in ropani) and working hours/day. Table 10 summarizes the basic characteristics for the sample households taken together.

Table 10: Descriptive Statistics for Sample Household

\begin{tabular}{llll}
\hline Parameters & Mean & Std. Deviation & $\mathbf{N}$ \\
\hline Family Income (Rs/day) & 448.79 & 331.98 & 321 \\
\hline Family Size & 4.22 & 1.59 & 321 \\
\hline Education Index & 19.25 & 15.45 & 321 \\
\hline Land Holding & .68 & 2.45 & 321 \\
\hline Working Hours & 14.46 & 8.36 & 321 \\
\hline
\end{tabular}

Table 11 shows that household income is positively correlated with family size, education and working hours.

Table 11: Correlation Coefficient (Pearson's)

\begin{tabular}{llllll}
\hline Parameters & $\begin{array}{l}\text { HH Income } \\
\text { (Rs/day) }\end{array}$ & $\begin{array}{l}\text { Family } \\
\text { Size }\end{array}$ & Education & $\begin{array}{l}\text { Land Holding } \\
\text { Size (Ropani) }\end{array}$ & $\begin{array}{l}\text { Working } \\
\text { Hours/day }\end{array}$ \\
\hline HH Income (Rs/day) & 1.000 & .314 & .349 & .021 & .519 \\
\hline Family Size & .314 & 1.000 & .641 & -.039 & .428 \\
\hline Education & .349 & .641 & 1.000 & -.013 & .392 \\
\hline Land Holding (in ropani) & .021 & -.039 & -.013 & 1.000 & -.007 \\
\hline Working Hours/day & .519 & .428 & .392 & -.007 & 1.000 \\
\hline
\end{tabular}

The results of linear multiple regressions are shown in Table 12. Stepwise regression using SPSS computer package was carried out. The criterion used for developing this model was the probability of 0.05 of ' $F$ ' to enter variables into the model and 0.10 for removal. The value multiple coefficient of determination ( $R$ squired) i.e. the proportion of the total variation in the ' $n$ ' observed values of the independent variable shows that only $30.1 \%$ of the total variation in the household income is explained by the model. 
Table 12: Variance Explained by Regression Model

Model Summary

\begin{tabular}{lllll}
\hline Model & R & R Square & Adjusted R-Square & Std. Error of the Estimate \\
\hline 1 & $.549(\mathrm{a})$ & .301 & .288 & 280.11 \\
\hline Predictors: (Constant), Land Holding, Working Hours, Education, Family Size, \\
\hline
\end{tabular}

T-values and its probability are generally used to identify the important independent variable affecting dependent variable. There is strong evidence that the intercept value is significant with probability value of ' $t$ ' distribution . Similarly, there is strong evidence that education and working hours are significantly related with household income ( Table 13).

Table 13: Values of regression model and its variables

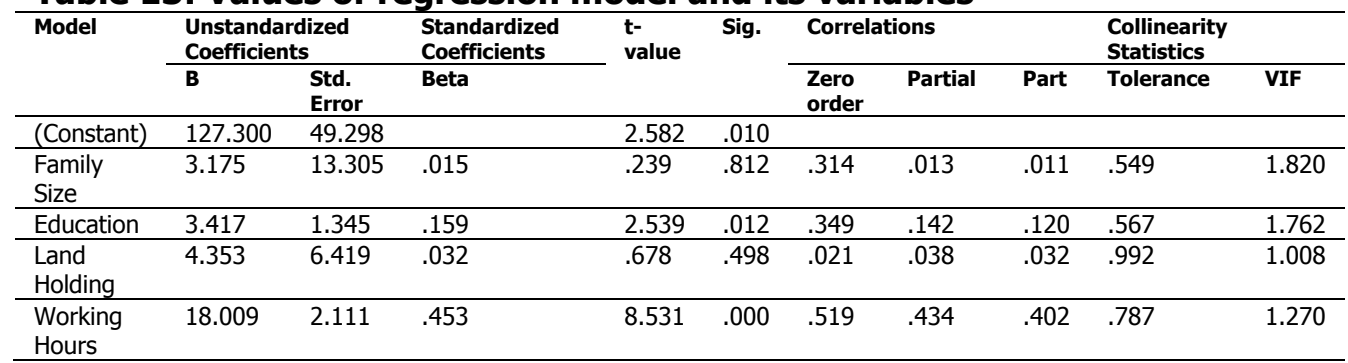

Dependent Variable: Household Income

\section{CONCLUSION}

Urban poor are assets of urban economy and are mostly involved in informal sector of urban economy. They have diversified and unstructured sources of income due to their irregular and seasonality of employment/works. The common areas of interests for earning cash are wage/labor, small scale business including vending; and private and professional services. Many youth are attracted either to private and professional services, which include secretarial services, repairing, maintenance and painting, or in the foreign employment in the gulf or south-east Asian countries. Statistical significance test of income generation activities by age, ethnic background and level of education, it is found that particular kind of activities are confined to specific age group and to given ethnic and education background. Ginicoefficient index also reflects the income inequality among the poor families. Similarly, amount of family income largely depends on ethnic background, working hours, nature and seasonality of works. Among other, there is a significant impact of education and working hour on household income.

It is true that, large numbers of poor families are living in the squatter and slum area, they are not only poor and unemployed but some of the economically well-off people are also living in the area. We could not neglect them; they are assets of urban economy, hard working and decent people; and contributing to boost informal sector of urban economy. However with poor policies and working mechanism, they are discouraged and largely ignored in the development process. They have poor accessed of modern banking and financial, in many cases, policies discouraged them for providing credit facilities. 


\section{NOTES}

- $\quad$ Central Zone refers to those areas which are playing as a centre role in terms of administration and business. This is the CBD zone and urban downtown of the Kathmandu Metropolitan City, where business and administrative function are recorded high and reported to high residential density. A middle zone includes these areas which has mixed land use particularly residential (medium residential density) cum commercial inside the ring road. In the periphery zone, in this study, defines the areas outside the ring road of Kathmandu Metropolitan City, which is relatively new urban expansion zone and having low residential density.

- It involved nutrition of per capita 2, $124 \mathrm{kcal}$ per day, selected food items and their average value, non-food items (calculated for clothing, rent, utilities, education, medicine, entertainment and other and the averages adopted by NLSS) were priced at average Kathmandu price and calculated on the basis of monetary value; and determined Rs 12,000 taking into the 2005 price level (Lumanti 2005, 12).

- The currency Converter, based on $1^{\text {st }}$ March 2010, International Monetary Fund. Available at http://www.CoinMill.com, [Accessed 02 March 2010].

- $\quad$ Lumanti Support Group for Shelter 2005 had conducted a survey on poverty income, employment and urban facilities in Kathmandu Metropolitan city, and defined; persons having an income of less than Rs. 12,000 have been categorized as poor; persons having an income range of Rs. 12,000 to 25,000 as lower medium; Rs. 25001 to Rs. 60,000 as medium and above Rs. 60,000 as upper medium and rich (Lumanti 2005, 12).

- The extent of inequality/unevenness between total number of families and total income is measured by an index known as 'Gini coefficient'. This coefficient is indicated by expressing it as ratio of area bounded between the equality line and the Lorenz curve. The coefficient index ranges from $0-1$. The index ' 0 ' represents perfect equality and ' 1 ' indicates a perfect inequality.

- In the study hill ethnic communities are refers to Janajaties and Minorities originated in hills and mountain region.

\section{REFERENCES}

Baker, Judy and Nina Schuler. 2004. Analyzing Urban Poverty, A Summary of Methods and Approaches. The World Bank. Policy Research Working Paper 3399.

Beall, Jo. and Stefan Schutte. 2006. Urban Livelihoods in Afghanistan. Synthesis Paper Series, Kabul: Afghanistan Research and Evaluation Unit. Available at http://www.areu.org.af [Accessed 18 December 2009].

Bowerman, Bruce. L. and Richard T. O'Connell. 1990. Linear Statistical Models, An Applied Approach. $2^{\text {nd }}$ ed. California: PWS-KENT Publishing Company, Duxbury Press.

Bryceson, D. F; T.C. Mbara; and A. S. C. Davis. 2003. Sustainable livelihoods, mobility and access needs. Crowthorne: TRL Limited. TRL Report TRL544. http://www.transport-links.org/transport_link/filearea/publications/1774_PA372.pdf [Accessed 02 December 2009].

Central Bureau of Statistics. 1997. Nepal Living Standards Survey Report 1996. Central Bureau of Statistics, National Planning Commission Secretariat Kathmandu.

Central Bureau of Statistics. 2004. Nepal Living Standards Survey 2003/04. Central Bureau of Statistics, National Planning Commission Secretariat Kathmandu.

Dawadi, Gaurab. S. 2008. Efficiency Measures in Informal Street Vendors of Urban Core Area of Kathmandu Metropolitan City. M.Sc.: Kathmandu, Institute of Engineering, Tribhuvan University.

Harpham, Trud. Tim Lusty and Patrick Vanghan. 1988. eds. In the Shadow of the City. Community Health and Urban Poor. Oxford University Press. 
Healey. Joseph, F. 1999. Statistics, A Tool for Social Research. $5^{\text {th }}$ ed. Wadsworth Publishing Company.

Hossain, Shahadat. 2005. Poverty, Household Strategies and Coping with Urban Life: Examining 'Livelihood Framework' in Dhaka City, Bangladesh. Bangladesh e-journal of Sociology. 2 (1), pp. 1-8.

Kathmandu Metropolitan City/World Bank. 2001. City Development Strategy and City Assistance Programme, Kathmandu Metropolitan City. Kathmandu: Kathmandu Metropolitan City/World Bank. Available at http://wwwwds.worldbank.org/external/default/WDSContentServer/WDSP/IB/2009/04/ 22/000334955_20090422071359/Rendered.pdf [Accessed 13 April 2010].

Lumanti. 2008. Status of Squatter Communities along Bagmati River and its tributaries in Kathmandu Valley. Kathmandu: Lumanti Support Group for Shelter.

Lumanti. 2005. A Survey on Poverty, Income, Employment and Urban Facilities in Kathmandu Metropolitan City. Kathmandu: Lumanti Support Group for Shelter.

Pal, Saroj K. 1982. Statistical Techniques, A Basic Approach to Geography. New Delhi: Tata McGraw-Hill Publishing Company Limited.

Pradhan, Puskar Kumar. 2008. Study on Status of Unemployed Slum Youth and Their Possible Linkages with Job Maret in Greater Kathmandu 2008. Kathmandu: CARE Nepal.

Raut, Uttam Bahadur. 2008. Urban Agriculture for Sustainable Urban development in Kathmandu. M.Sc.: Kathmandu: Institute of Engineering, Tribhuvan University.

Sarin, Ankur and Rekha Jain. 2009. Effect of Mobiles on Socio-economic life of Urban Poor. Ahmedabad: Indian Institute of Management. Working Paper no 2009-02-05.

Schutte, Stefan. 2006. Poor, Poorer, Poorest: Urban Livelihoods and Vulnerability in Mazar-i-Sharif. Kabul: Afghanistan Research and Evaluation Unit (AREU). www.geo.fuberlin.de/geog/fachrichtungen/anthrogeog/zelf/median/downlo aded/schuette [Accessed 29 September 2009].

Shrestha, Bhusan R. 2008. Status of Squatters in Bagmati River and its Tributaries in Kathmandu Valley- 2008. (Draft report). Kathmandu: Lumanti Support Groups for Shelter.

Timalsina, K P. 2007. Rural Urban Migration and Livelihood in Informal Sector, $A$ Study of Street Vendors of Kathmandu Metropolitan City, Nepal. M.Phil. Trondheim: Development Studies, Department of Geography, Norwegian University of Science and Technology (NTNU).

World Bank. 2007. Dhaka: Improving Living Conditions for the Urban Poor. Dhaka: The World Bank Office. Bangladesh Development Series Paper No 17. 


\section{Annex}

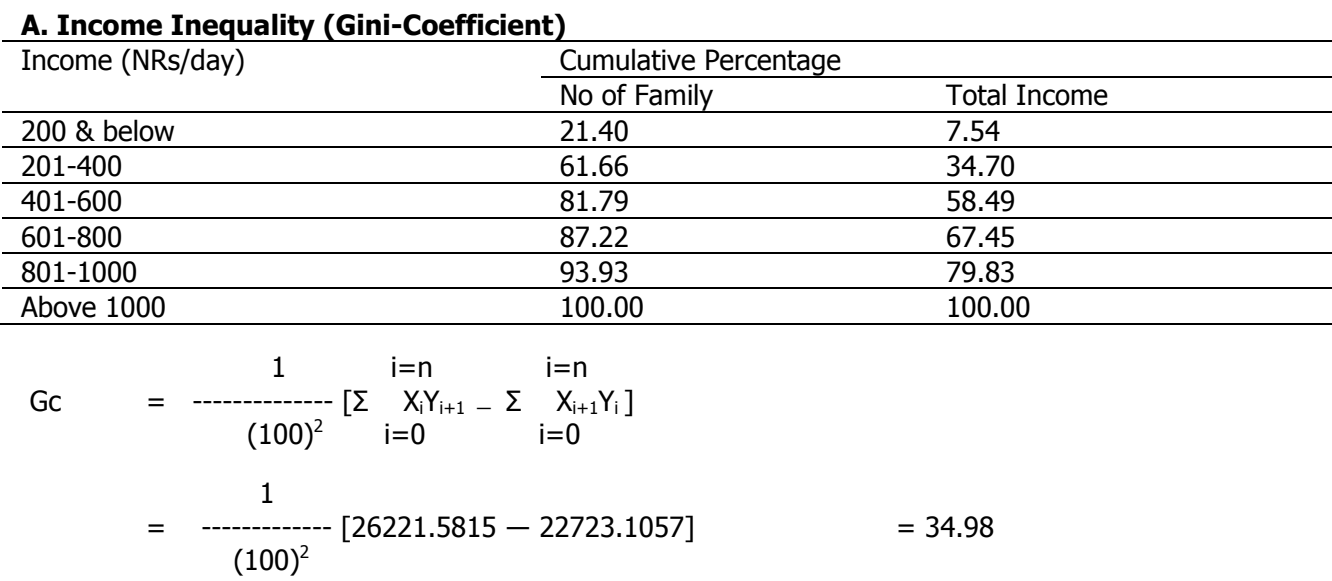

Result: Tending towards inequality of income among the poor families in Kathmandu. It also assumes that the income is concentrated for some families living in the poverty pockets.

\section{B. Household Income by Ethnic Background}

Null Hypothesis $\left(\mathrm{H}_{0}\right)$ : Household income and ethnic background are independent.

Alternative Hypothesis $\left(\mathrm{H}_{1}\right)$ : Both variables are dependent.

\section{Observed Frequency $\left(f_{o}\right)$}

\begin{tabular}{llllll}
\hline \multicolumn{1}{l}{ Observed Frequency $\left(\boldsymbol{f}_{\boldsymbol{o}}\right)$} & $\begin{array}{l}\text { Brahmin \& } \\
\text { Chhetri }\end{array}$ & Janajati \& Minorities & Dalits & Newar \& Others & Total \\
\hline Rs 200 \& less & 20 & 31 & 5 & 11 & 67 \\
\hline Rs 201-400 & 24 & 66 & 21 & 15 & 126 \\
\hline Rs 401-600 & 15 & 32 & 3 & 13 & 63 \\
\hline Rs 601-800 & 5 & 10 & 1 & 1 & 21 \\
\hline Rs 801-1000 & 8 & 10 & 3 & 1 & 19 \\
\hline Above Rs 1000 & 5 & 10 & 34 & 43 & 313 \\
\hline Total & 77 & 159 & & & 21 \\
\hline
\end{tabular}

\section{Expected Frequency $\left(f_{e}\right)$}

\begin{tabular}{llllll}
\hline & Brahmin \& Chhetri & Janajati \& Minorities & Dalits & Newar \& Others & Total \\
\hline Rs 200 \& less & 16.48 & 34.04 & 7.28 & 9.20 & 67 \\
\hline Rs 201-400 & 31.00 & 64.00 & 13.69 & 17.31 & 126 \\
\hline Rs 401-600 & 15.50 & 32.00 & 6.84 & 8.66 & 63 \\
\hline Rs 601-800 & 4.18 & 8.64 & 1.85 & 2.33 & 17 \\
\hline Rs 801-1000 & 5.17 & 10.67 & 2.28 & 2.88 & 21 \\
\hline Above Rs 1000 & 4.67 & 9.65 & 2.06 & 2.62 & 19 \\
\hline Total & 77.00 & 159.00 & 34.00 & 43.00 & 313 \\
\hline
\end{tabular}

Chi-square $\left(x^{2}\right)$ (Obtained) $=\sum \begin{gathered}\left(f_{o}-f_{e}\right)^{2} \\ -f_{e}\end{gathered}$

$=(0.75+1.58+0.20+0.16+1.55+0.02)+(0.27+0.06+0.00+0.21+0.04+0.01)+(0.71+3.90+2.16+0.39+0.72+0.42)+$ $(0.35+0.31+2.17+0.76+0.27+1.00)$ $=18.02$

Degree of Freedom (Df) $=(r-1)(c-1)=(6-1)(4-1) \quad=15$

$X^{2}$ (Critical) at 0.05 significance level $=24.996$

Result: $\mathrm{H}_{0}$ Accepted. Household income is not controlled by ethnic dimension of population. Both variables are independent. 